\title{
Detection and Characterization of a Lethal Yellowing (16SrIV) Group Phytoplasma in Canary Island Date Palms Affected by Lethal Decline in Texas
}

\author{
N. A. Harrison, University of Florida, Fort Lauderdale Research and Education Center, Fort Lauderdale 33314; M. \\ Womack, Texas Agriculture Extension Service, Texas A\&M University, Robstown, TX 78380; and M. L. Carpio, \\ University of Florida, Fort Lauderdale Research and Education Center
}

\begin{abstract}
Harrison, N. A., Womack, M., and Carpio, M. L. 2002. Detection and characterization of a lethal yellowing (16SrIV) group phytoplasma in Canary Island date palms affected by lethal decline in Texas. Plant Dis. 86:676-681.

Polymerase chain reaction (PCR) assays were used to detect phytoplasmas in Canary Island date (Phoenix canariensis) palms displaying symptoms similar to lethal yellowing (LY) disease in Corpus Christi, TX. An rDNA product $(1.8 \mathrm{~kb})$ was amplified consistently from 10 of 11 palms by PCR employing phytoplasma universal rRNA primer pair P1/P7. Also, AluI endonuclease digests and sequencing of P1/P7 products revealed that nontarget Bacillus megateriumrelated rDNA sequences of similar size were co-amplified along with phytoplasma rDNA from 10 palms. A 1,402-bp product was obtained from all 11 symptomatic palms when initial P1/P7 products were reamplified by PCR employing nested LY phytoplasma group-specific 16S rRNA primer pair LY16Sf/LY16Sr. Restriction fragment length polymorphism (RFLP) analysis of nested PCR products revealed that palm-infecting phytoplasmas were uniform and most similar to strains composing the coconut lethal yellowing phytoplasma (16SrIV) group. Sequence analysis of $16 \mathrm{~S}$ rDNA determined the Texas Phoenix palm decline (TPD) phytoplasma to be phylogenetically closest to the Carludovica palmata leaf yellowing (CPY) phytoplasma. rDNA profiles of strains TPD and CPY obtained with $A l u$ I were co-identical and distinct from other known 16SrIV group phytoplasmas. On this basis, both strains were classified as members of a new subgroup, 16SrIV-D.
\end{abstract}

Additional keywords: Arecaceae, phytoplasma identification

Canary Island date (Phoenix canariensis Chabaud) palms are widely used for their aesthetic appeal in landscape and amenity plantings in southern Texas. A decline disease affecting mature Phoenix palms was first recognized in the Corpus Christi area of Nueces County, TX, during 2001. Symptoms observed on affected palms include death of adventitious roots, inflorescence necrosis, and a progressive browning and desiccation of successively younger leaves. At an advanced stage, foliar discoloration encompasses all leaves in the crown. Presently, in plantings of Canary Island palms at several locations where symptomatic palms have been identified, not all palms within the plantings are necessarily affected, although palms that have died are also evident. Overall,

Corresponding author: Nigel A. Harrison

E-mail: naha@ufl.edu

GenBank accession number of DNA sequence: AF434989.

Florida Agricultural Experiment Station Journal Series No. R-08418.

Accepted for publication 18 February 2002.

Publication no. D-2002-0415-01R

(C) 2002 The American Phytopathological Society symptoms on palms closely resemble those observed previously on Phoenix palms ( $P$. canariensis and $P$. dactylifera) during an outbreak of a lethal decline disease which killed large numbers of palms in the Brownsville area and lower Rio Grande Valley of southern Texas during the late 1970s (21). On the basis of symptomatology, pattern of spread, presence of phytoplasmas in palm tissues, and species of palms affected, the latter disease was considered to be synonymous with lethal yellowing (LY) disease (22), which was widespread on palms in southern Florida at that time (20).

The present study was undertaken in August 2001 to determine the etiology of Texas Phoenix palm decline. We report the detection of coconut lethal yellowing (16SrIV) group phytoplasmas in the symptomatic $P$. canariensis palms sampled in Corpus Christi. Detected phytoplasmas were genetically similar, distinct from the LY agent, and phylogenetically most closely related to the Carludovica palmata yellows (CPY) agent, a 16SrIV group phytoplasma previously described from southern Mexico (2).

\section{MATERIALS AND METHODS}

Plant samples and phytoplasma reference strains. Tissue samples consisting of wood shavings (about $6 \mathrm{~g}$ ) were removed from interior basal trunks of 11 symptomatic Canary Island date palms growing in Corpus Christi. Samples were excised by boring a hole 10 to $15 \mathrm{~cm}$ in length into each palm trunk using a portable electric drill and 5/16 in. (ca. $7.8 \mathrm{~mm}$ ) diameter bit. Prior to sampling each palm, the bit was rinsed with water from a squirt bottle, flame-sterilized using a portable propane torch, and cooled by a second rinse with water. Tissue shavings were collected directly into clean sealable plastic bags. A mature, symptomless $P$. canariensis palm located on the grounds of the University of Florida's Fort Lauderdale Research and Education Center (FLREC) was also sampled by this method. Texas palm samples were shipped by overnight courier to the FLREC for further processing.

Phytoplasmas used for comparative purposes included the following strains: elm yellows (EY1) (5), ash yellows (AshY3) (6), western $X(W X)$, Mexican periwinkle virescence (MPV) (8), eastern aster yellows (EAY), pigeon pea witches'-broom (PPWB) (12), each maintained separately in periwinkle (Catharanthus roseus (L.) G. Don). DNA of the palm lethal yellowing (LY) phytoplasma was obtained from inflorescence tissue of a coconut palm (Cocos nucifera L.) in Florida with typical LY symptoms (20). DNA of Yucatan coconut lethal decline (LDY) (10), Carludovica palmata ('palma jipi') yellows (CPY) (2), Bermudagrass (Cynodon dactylon) white leaf (BGWL), sweet potato (Ipomoea batatas) little leaf (SPLL), and beet leafhoppertransmitted virescence (BLTVA) phytoplasmas were provided to us by other researchers.

DNA extraction. The nucleic acid extraction procedure of Doyle and Doyle (4) was used for all plant tissue samples after first grinding samples in a mortar and pestle with sea-washed sand to facilitate the grinding process. Each resulting nucleic acid extract was precipitated with ethanol, pelleted by centrifugation, resuspended in 150 or $200 \mu \mathrm{l}$ of TE $(10 \mathrm{mM}$ Tris, $1.0 \mathrm{mM}$ EDTA, pH 8) buffer, and treated with RNase for $1 \mathrm{~h}$ at $37^{\circ} \mathrm{C}$. DNA were quantified by fluorometry (TKO-100 minifluorometer, Hoefer Scientific, San Francisco, CA) and stored at $4^{\circ} \mathrm{C}$ before use. Aliquots $(50 \mu \mathrm{l})$ of each Phoenix palm DNA were purified separately on spin columns (GeneClean, Q-BIOgene, Vista, $\mathrm{CA}$ ) and eluted in $25 \mu \mathrm{l}$ of ultrapure water. 
Polymerase chain reaction (PCR) analysis. Amplifications were performed in $50 \mu \mathrm{l}$ final reaction volumes each containing $50 \mathrm{ng}$ of DNA template, $50 \mathrm{ng}$ of each primer, $125 \mu \mathrm{M}$ of each dNTP, $1 \mathrm{U}$ of Taq DNA polymerase (Promega Corp., Madison, WI), and standard PCR buffer with $1.5 \mathrm{mM} \mathrm{MgCl}_{2}$ (14). PCR was performed for 30 cycles in a PTC/100 programmable thermal controller with hot bonnet (MJ Research Inc., Watertown, MA) employing phytoplasma universal rRNA primer pair P1 and P7 (30) and previously described thermal cycling conditions (9). Products of P1/P7-primed PCR were diluted $1: 40$ or $1: 100$ with sterile deionized water and 2 or $4 \mu \mathrm{l}$ of each dilution then used as template during 35 cycles of PCR with nested rRNA primer pair LY16Sf (5'-CATGCAAGTCGAACGGAA ATC- $\left.3^{\prime}\right)$ and LY16Sr (5'-GCTTACGCA GTTAGGCTGTC-3'), which were designed in this study from a $16 \mathrm{~S}$ rDNA sequence of the LY phytoplasma (GenBank accession U18747). For nested PCR, the following thermal cycling parameters were used: denaturation for $30 \mathrm{~s}(2 \mathrm{~min} 30 \mathrm{~s}$ for first cycle) at $94^{\circ} \mathrm{C}$, annealing for $50 \mathrm{~s}$ at $60^{\circ} \mathrm{C}$, and extension for $80 \mathrm{~s}$ at $72^{\circ} \mathrm{C}$. Reactions were terminated by a $10-\mathrm{min}$ extension step and cooled to $4^{\circ} \mathrm{C}$. Palm DNAs were also assayed by PCR (40 cycles) employing nonribosomal primers LYF1 and LYR1 as previously described (11). While the latter assay has been used to reliably detect the LY agent, a subgroup 16SrIV-A phytoplasma (17) infecting coconut and other palm species in the Caribbean, it does not detect other strains classified as coconut lethal yellowing (16SrIV) group members $(2,10)$. Aliquots $(10 \mu \mathrm{l})$ of each final reaction mixture were electrophoresed through $1 \%$ agarose (low EEO, Fisher Scientific, Pittsburgh, PA) gels using TAE (40 mM Tris-acetate, $1 \mathrm{mM}$ EDTA) as running buffer. DNA products in gels were stained with ethidium bromide (EtBr), visualized by UV transillumination, and photographed.

Restriction fragment length polymorphism (RFLP) analysis of PCR products. Products of P1/P7-primed PCR were digested separately with $10 \mathrm{U}$ of restriction endonuclease AluI (Promega), whereas nested rDNA products from reamplifications of $\mathrm{P} 1 / \mathrm{P} 7$ products by LY16Sf/ LY16Sr-primed PCR were digested separately with AluI, HinfI (New England Biolabs, Beverly, MA), DdeI, HhaI, or RsaI at $37^{\circ} \mathrm{C}$, and TaqI or Tru9I (Promega) at $65^{\circ} \mathrm{C}$, for a minimum of $16 \mathrm{~h}$. Digests were separated by electrophoresis through $8 \%$ nondenaturing polyacrylamide gels using TBE (90 mM Tris-borate, $2 \mathrm{mM}$ EDTA) as running buffer. Products in gels were visualized and recorded as described above.

Cloning and sequencing of PCR products. $\mathrm{P} 1 / \mathrm{P} 7$-primed rDNA products amplified from Phoenix palm TPD2, or from DNAs of phytoplasmas LDY and
CPY, were purified on spin columns (QIAquick PCR Purification Kit, Qiagen, Valencia, CA), eluted with sterile ultrapure water, and cloned in vector pGEM-T (Promega) and Escherichia coli DH5 $\alpha$ cells (BRL Life Technologies, Rockville, $\mathrm{MD})$ according to the manufacturer's instructions. Two representative clones derived from palm TPD2 were sequenced at the University of Florida's Core DNA sequencing laboratory.

Analysis of phytoplasma rDNA. Pairwise similarities between rDNA sequences were calculated by Gap analysis (Wisconsin package Version 10.1, Genetics Computer Group [GCG], Madison, WI). For phylogenetic analysis, $16 \mathrm{~S}$ rDNA sequences of the TPD phytoplasma, 28 other phytoplasma strains representing at least 15 primary phytoplasma groups $(17,23)$, and Acholeplasma laidlawii (Table 1) were edited and aligned using SeqEd and PileUp programs (Wisconsin package Version 10.1). Pairwise evolutionary distances between aligned sequences were created by Distances (SeqWeb version 1.2, GCG) incorporating the Kimura-2 parameter distance correction method. A phylogenetic tree was constructed by Neighbor-Joining from the distance matrix using GrowTree (SeqWeb) and visualized by TreeView (26).

\section{RESULTS}

Phytoplasma detection in Phoenix palms. Initially, phytoplasmas were detected in trunk tissues from four of 11 (36.4\%) declining Texas Phoenix palms only by P1/P7-primed PCR. Positive detections were indicated by weak or moderate amplification of an rDNA product of about $1.8 \mathrm{~kb}$. Failure to amplify a discernible product from the majority $(63.6 \%)$ of Phoenix palm samples was attributed to inhibitory components present in sample DNA preparations. This was evident after PCRs were repeated with all negatively testing palm DNAs and failed once again to yield an rDNA product even though each reaction mixture was augmented with 50 ng of known amplifiable LY phytoplasma DNA (data not shown). After further purification of DNA on spin columns, positive detections were obtained for 10 of $11(90.9 \%)$ palms using P1/P7-primed PCR (Fig. 1A). Comparable size rDNA products were amplified from DNA of the LY phytoplasma as well as rDNA products cloned from the CPY and LDY agents included as positive controls in each experiment. By comparison, no PCR product was obtained from DNA from trunk tissue of a symptomless Florida grown $P$. canariensis palm or in mixtures devoid of

Table 1. Description of phytoplasma 16S rDNA sequences used in this study

\begin{tabular}{|c|c|c|c|}
\hline Phytoplasma or associated disease & $\begin{array}{l}\text { 16S rRNA group- } \\
\text { subgroup affiliation }\end{array}$ & $\begin{array}{c}\text { GenBank } \\
\text { accession no. }\end{array}$ & Ref. \\
\hline Michigan aster yellows (MiAY) & $16 \mathrm{SrI}-\mathrm{B}$ & M30790 & 18 \\
\hline Western severe aster yellows (SAY) & 16SrI-B & M86340 & 16 \\
\hline $\begin{array}{l}\text { Japanese hydrangea phyllody (JHP) } \\
\text { ("Candidatus Phytoplasma japonicum") }\end{array}$ & 16SrI-D & $\mathrm{AB} 010425$ & 27 \\
\hline Peanut witches'-broom (PnWB) & 16SrII-A & L33765 & 7 \\
\hline Sweet potato witches'-broom (SPWB) & 16SrII-A & L33770 & 7 \\
\hline Sunnhemp witches'-broom (SUNHP) & 16SrII-A & X76433 & 29 \\
\hline $\begin{array}{l}\text { Witches'-broom disease of lime (WBDL) } \\
\text { ("Candidatus Phytoplasma aurantifolia") }\end{array}$ & 16SrII-B & U15442 & 36 \\
\hline $\begin{array}{l}\text { Papaya yellow crinkle (PpYC) } \\
\text { ("Candidatus Phytoplasma australasia") }\end{array}$ & 16SrII-E & Y10097 & 34 \\
\hline Western X (WX) & 16SrIII-A & L04682 & 7 \\
\hline Clover yellow edge (CYE) & 16SrIII-B & L33766 & 7 \\
\hline Palm lethal yellowing (LY) & 16SrIV-A & U18747 & 32 \\
\hline Yucatan coconut lethal decline (LDY) & 16SrIV-B & U18753 & 32 \\
\hline Coconut lethal disease, Tanzania (LDT) & 16SrIV-C & X80117 & 32 \\
\hline Carludovica palmata yellows (CPY) & 16SrIV-D & AF237615 & 2 \\
\hline Texas Phoenix decline (TPD) & 16SrIV-D & AF434989 & $\begin{array}{l}\text { This } \\
\text { article }\end{array}$ \\
\hline Cape St. Paul wilt (LDG) & Unclassified & Y14175 & 32 \\
\hline Elm yellows (EY1) & 16SrV-A & AF122910 & 5 \\
\hline Clover proliferation $(\mathrm{CP})$ & 16SrVI-A & L33761 & 7 \\
\hline $\begin{array}{l}\text { Ash yellows (AshY1) } \\
\text { ("Candidatus Phytoplasma fraxini”) }\end{array}$ & 16SrVII-A & AF092209 & 6 \\
\hline Loofah witches'-broom (LfWB) & 16SrVIII-A & L33764 & 7 \\
\hline Pigeon pea witches'-broom (PPWB) & 16SrIX-A & U18763 & 32 \\
\hline Apple proliferation (AT) & $16 \mathrm{SrX}-\mathrm{A}$ & X68375 & 29 \\
\hline Buckthorn witches'-broom (BWB) & 16SrX-E & X76431 & 29 \\
\hline Rice yellow dwarf (RYD) & 16SrXI-A & D12581 & 24 \\
\hline Stolbur (STOL) & 16SrXII-A & X76427 & 29 \\
\hline $\begin{array}{l}\text { Australian grapevine yellows (AUGY) } \\
\text { ("Candidatus Phytoplasma australiense") }\end{array}$ & $16 \mathrm{SrXII}-\mathrm{B}$ & X95706 & 25 \\
\hline Mexican periwinkle virescence (MPV) & 16SrXIII-A & AF248960 & 3 \\
\hline Bermudagrass white leaf (BGWL) & 16SrXIV & Y16388 & 29 \\
\hline $\begin{array}{l}\text { Hibiscus witches'-broom (HibWB) } \\
\text { ("Candidatus Phytoplasma brasiliense") }\end{array}$ & $16 \mathrm{SrXV}$ & AF147708 & 23 \\
\hline Acholeplasma laidlawii & Not applicable & M23932 & 33 \\
\hline
\end{tabular}


template DNA which also served as negative experimental controls.

Phytoplasma characterization. Potential relatedness of phytoplasmas associated with Texas Phoenix palm decline (TPD) and LY implied by symptomatological similarities between diseases was substantiated upon reamplification of primary P1/P7 products by PCR employing nested 16S rRNA primer pair LY16Sf/LY16Sr. The assay generated an rDNA product about $1.4 \mathrm{~kb}$ in size from DNA of the LY phytoplasma and a product of similar size from all 11 (100\%) symptomatic Phoenix palms (Fig. 1B). In addition, comparable products were amplified from cloned rDNA of the CPY and LDY agents, whereas no product was generated from DNAs of either symptomless $P$. canariensis palm or phytoplasma strains representative of nine other established phylogenetic groups of phytoplasmas (data not shown). When purified $P$. canariensis DNA samples were examined by PCR incorporating LY-specific nonribosomal primer pair LYF1/R1, no discernible product was amplified from any of these samples. Likewise, no product was amplified from DNA of symptomless $P$. canariensis or from CPY and LDY rDNA templates, whereas a product of expected size (about $1 \mathrm{~kb}$ ) was readily amplified from DNA of the LY phytoplasma (data not shown). Lack of amplification of rDNA from Texas Phoenix palms by this assay indicated that phytoplasmas in these palms varied from the LY agent.
AluI digests of $\mathrm{P} 1 / \mathrm{P} 7$ products yielded rDNA fragment profiles suggesting the presence of two distinct phytoplasmas in Texas Phoenix palm samples (Fig. 2). One profile consisting of five fragments was obtained from palms TPD2, TPD5, and TPD6. This profile most closely resembled that of the LY phytoplasma included for comparative purposes. A second profile consisting of eight fragments was generated for palms TPD7, TPD10, and TPD11, while a mixture of both profiles was associated with palms TPD3, TPD4, and TPD8. Phoenix palms TPD1 and TPD9 yielded insufficient $\mathrm{P} 1 / \mathrm{P} 7$ product to permit RFLP analysis.

Nested rDNA products resulting from reamplification of primary $\mathrm{P} 1 / \mathrm{P} 7$ products by LY16Sf/LY16Sr-primed PCR were analyzed by digestion with $A l u \mathrm{I}, D d e \mathrm{I}$, HinfI, RsaI, TaqI, Tru9I (Fig. 3), or HhaI (data not shown). This selection of endonucleases was used after putative restriction site analysis predicted that they would provide the most informative digests for detection of sequence variation within $16 \mathrm{~S}$ rDNA of known lethal yellowing (16SrIV) group phytoplasmas (data not shown). Collectively, these enzymes failed to reveal any differences between $16 \mathrm{~S}$ rDNA products amplified from Phoenix palms, indicating that very similar or possibly the same phytoplasma was present in these palms. Also, it was evident upon comparison with known $16 \mathrm{SrIV}$ group phytoplasmas that collective rDNA profiles generated from the TPD phytoplasma and strain

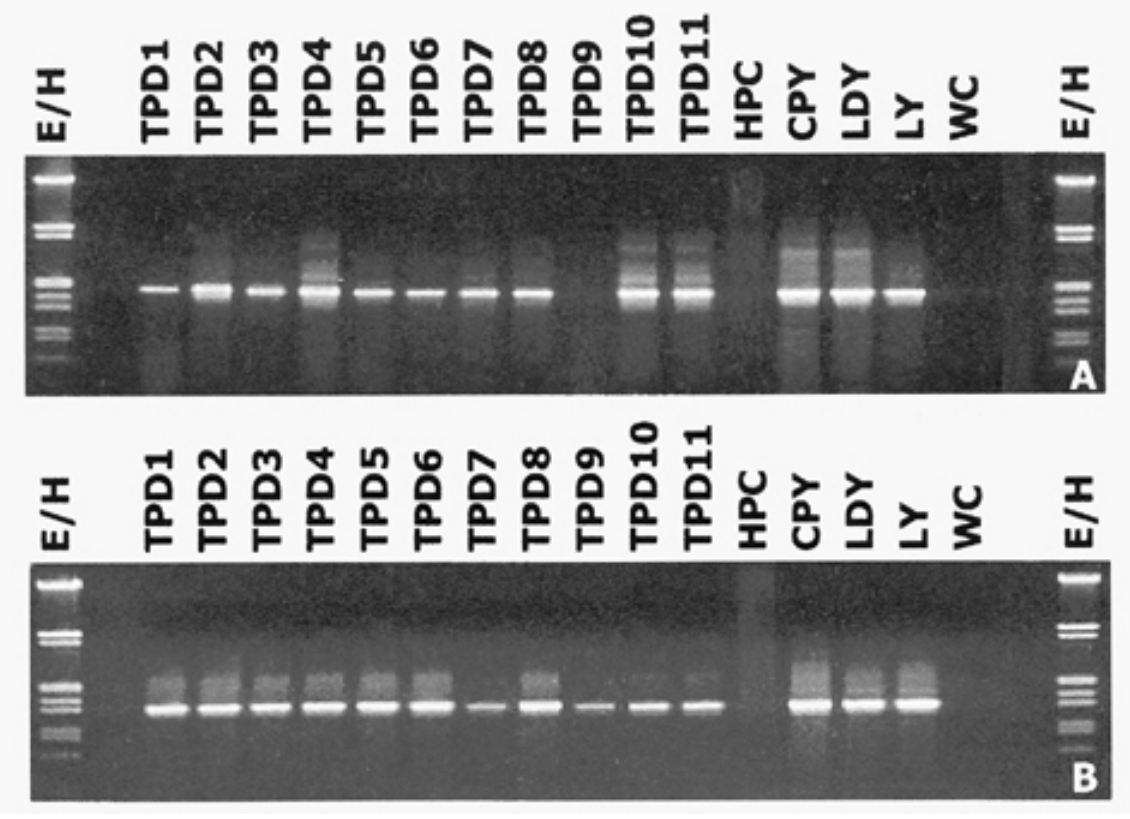

Fig. 1. Agarose gel electrophoresis of rDNA products amplified from DNAs of lethal declineaffected Canary Island date (Phoenix canariensis) palms by polymerase chain reaction (PCR) assays. A, Products generated using the phytoplasma universal rRNA primer pair P1/P7 and B, reamplification of P1/P7 products with nested rRNA primer pair LY16Sf/LY16Sr. Template DNA samples were derived from: TPD, symptomatic Texas $P$. canariensis palms; HPC, symptomless $P$. canariensis; CPY, Carludovica palmata leaf yellowing phytoplasma; LDY, Yucatan coconut lethal decline phytoplasma; LY, coconut lethal yellowing phytoplasma; and WC, water control. E/H, HindIII/EcoRI digested $\lambda$ DNA.
CPY were co-identical. Furthermore, $A l u \mathrm{I}$ digests (Fig. 3A) yielded profiles differentiating TPD and CPY phytoplasmas from 16SrIV-B subgroup strain LDY, whereas AluI, HinfI, DdeI, RsaI, and Tru9I digests each distinguished strains TPD, CPY, and LDY from 16SrIV-A subgroup strain LY.

Cloning and sequence similarities between phytoplasma rRNA operon sequences. $\mathrm{P} 1 / \mathrm{P} 7$ products cloned from Texas Phoenix palm TPD2 in vector pGEM-T and reamplified by P1/P7-primed PCR were analyzed by $A l u \mathrm{I}$ digestion. Two different rDNA fragment profiles were evident among the 14 clones examined by this means, indicating that two dissimilar products of the same approximate size were amplified from this symptomatic palm. One profile derived from clone TPD2-A (Fig. 4) and 12 other rDNA clones matched those observed previously after P1/P7 products amplified directly from palms TPD2, TPD5, and TPD6 were digested with $A l u$ I (Fig. 2). A second profile revealed by digestion of clone TPD2-B (Fig. 4) was similar to AluI profiles of P1/P7 products amplified directly from palms TPD7, TPD10, and TPD11 (Fig. 2).

Pairwise similarities between 16S rDNA sequences derived from cloned P1/P7 product TPD2-A and other 16SrIV group phytoplasmas ranged from $99.21 \%$ to $100 \%$, respectively. These values are consistent with a phytoplasma origin of the cloned rDNA sequence and classification of the associated strain (TPD) in the coconut lethal yellowing (16SrIV) phytoplasma group. The rDNA sequence of the TPD phytoplasma determined in this study has been deposited in the GenBank database under accession number AF434989. A search (1) of the GenBank database re-

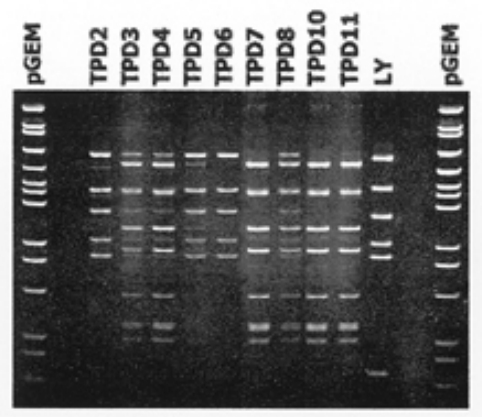

Fig. 2. Comparison of restriction fragment profiles resulting from $A l u \mathrm{I}$ endonuclease digestion of rDNA products $(1.8 \mathrm{~kb})$ amplified from phytoplasma-infected palms by a polymerase chain reaction (PCR) assay using rRNA primer pair P1/P7. Fragment profiles were resolved by ethidium bromide staining after electrophoresis through an $8 \%$ polyacrylamide gel. PCR products were derived from the following DNA templates: TPD, symptomatic Texas Phoenix canariensis palms; and LY, coconut lethal yellowing phytoplasma. pGEM, molecular size (bp) markers in descending order: 2,465, 1,605, 1,198, 676, 517, 460, 396, $350,222,179,126,75,65,51,36$. 
vealed a $>99 \%$ similarity between the sequence of cloned $\mathrm{P} 1 / \mathrm{P} 7$ product TPD2-B and an rDNA sequence from Bacillus megaterium (15) and no significant similarity to phytoplasma rRNA operon sequences. Thus, earlier ambiguous fragment profiles observed following AluI digestion of P1/P7 products (Fig. 2) and interpreted tentatively to reflect mixed infection of Phoenix palms by two dissimilar phytoplasmas were due instead to coamplification of nontarget rDNA sequences with phytoplasma rDNA during P1/P7primed PCR. Subsequently, primer pair bmeg-f (5'-TGGGAGATGATTGAAAGA TG-3') and bmeg-r (5'-CTAAATGCT GGCAACTAAGA- $3^{\prime}$ ) derived from the TPD2-B sequence and used in PCR (30 cycles, primer annealing at $60^{\circ} \mathrm{C}$ ) amplified a 955-bp B. megaterium-related rDNA sequence from all Texas Phoenix palm DNA samples except palm TPD9. Also, no product was generated from DNA of a symptomless, Florida-grown $P$. canariensis palm by this assay (data not shown).

Phylogenetic analysis. A phylogenetic distance tree was constructed from a data set which included 16S rDNA sequences of the TPD phytoplasma, 28 additional strains of phytoplasmas, and A. laidlawii (Fig. 5). Tree branching orders resolved by this analysis were similar to and supported the same major phylogenetic groups identified in other studies $(3,7,32)$. Also in this analysis, the TPD phytoplasma clustered closely together with other known coconut lethal yellowing (16SrIV) group strains, thereby supporting its assignment to this group. Tree branching patterns also indicated that the TPD phytoplasma was evolutionarily closest to CPY, a phytoplasma not included in previous phylogenetic trees, and part of an existing lineage of strains that includes LDY.

\section{DISCUSSION}

One unexpected outcome to evaluating $P$. canariensis trunk phloem for evidence of phytoplasma infection by $\mathrm{P} 1 / \mathrm{P} 7$-primed PCR was that nontarget $B$. megateriumrelated rDNA sequences of similar size were co-amplified with phytoplasma rDNA from most symptomatic palms during this assay. B. megaterium is a soil saprobe and component of rhizosphere microflora (19) whose potential for use as a biocontrol agent against Rhizoctonia root rot has been recently investigated (35). Although the origin of this innocuous contaminant was not determined, the spongy "bark" composed of a thick, outermost layer of dried, necrotic leaf bases on Canary Island date palm trunks seemed a likely source. As no attempt was made to remove this layer prior to sampling, fragments of bark were unavoidably mixed in with those of underlying living wood when the latter target tissue shavings were excised from palms by boring holes into their trunks.

By confirming presence of phytoplasmas in symptomatic Corpus Christi Phoenix palms, this newly emergent disease closely resembles a previous description of another phytoplasma-associated disease which killed both Canary Island date and true date $(P$. dactylifera) palms in the Brownsville area and lower Rio Grande valley of Texas over two decades ago (21). Supported by epidemiological observations including host range, jump-spread pattern of dissemination, and rate of spread, the disease was considered to be lethal yellowing (22). However, this earlier outbreak predated DNA-based techniques now used routinely to detect and characterize phytoplasmas. Consequently, the true identity of phytoplasmas infecting Brownsville area Phoenix palms was never determined. Today, the disease is no longer active, precluding a comparison of Phoenix palminhabiting phytoplasmas at this location and at Corpus Christi in the present study.

Our identification of TPD phytoplasmas as strains belonging to $16 \mathrm{~S}$ rDNA RFLP group 16SrIV sensu Lee et al. (17) extends the known northernmost distribution of lethal yellowing group phytoplasmas in the United States. Within group 16SrIV, previously characterized strains LY, LDY, and TLD have been delinated further into sub-
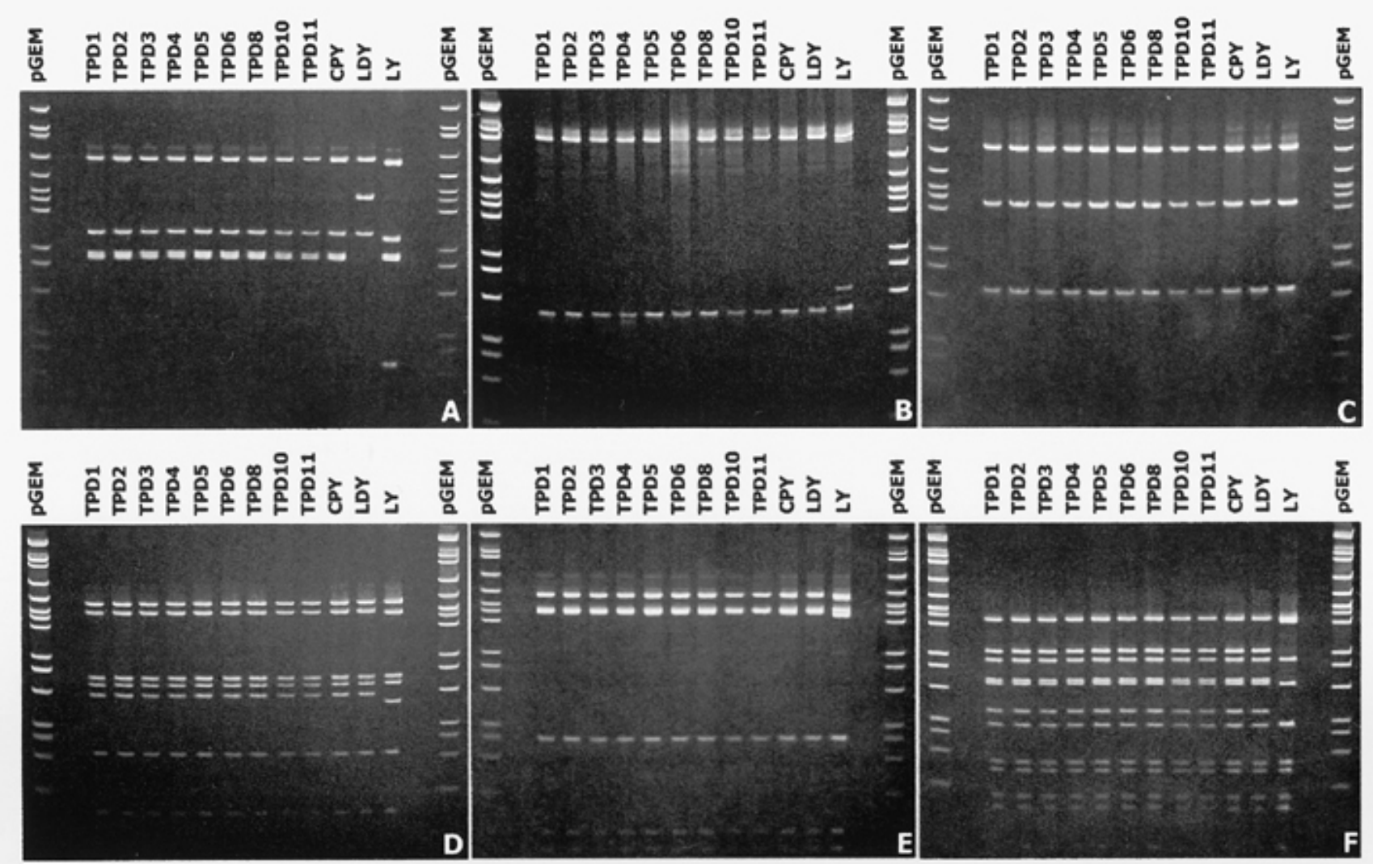

Fig. 3. Comparison of fragment profiles resulting from restriction endonuclease digestion of rDNA products (1.39 kb) reamplified from symptomatic Texas Phoenix canariensis palms by a polymerase chain reaction (PCR) assay incorporating nested 16S rRNA primer pair LY16Sf/LY16Sr. Template DNA for PCR were derived from TPD, symptomatic Texas P. canariensis palms; CPY, Carludovica palmata leaf yellowing phytoplasma; LDY, Yucatan coconut lethal decline phytoplasma; and LY, coconut lethal yellowing phytoplasma, and digested with A, AluI, B, HinfI, C, TaqI, D, DdeI, E, RsaI, and F, Tru9I. pGEM, molecular size (bp) markers in descending order: 2,465, 1,605, 1,198, 676, 517, 460, 396, 350, 222, 179, 126, 75, 65, 51, 36. 


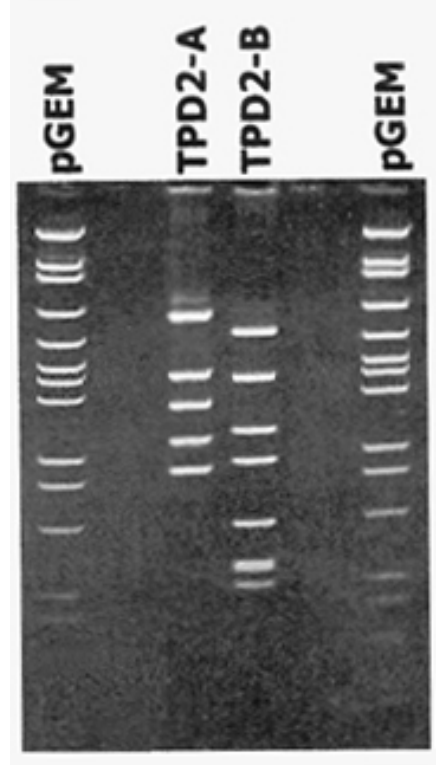

Fig. 4. $A l u \mathrm{I}$ endonuclease digests of rDNA products co-amplified from Texas Phoenix canariensis palm TPD2 by a polymerase chain reaction assay with phytoplasma universal rRNA primer pair P1/P7. Products were cloned in vector pGEM-T and Escherichia coli DH5- $\alpha$ cells and identified by sequencing as: TPD2-A, an rDNA sequence derived from the Texas Phoenix decline phytoplasma; TPD2-B, Bacillus megaterium-related rDNA sequence. pGEM, molecular size (bp) markers in descending order: $2,465,1,605,1,198,676,517$, $460,396,350,222,179,126,75,65,51,36$.

groups 16SrIV-A, 16SrIV-B, and 16SrIV$\mathrm{C}$, respectively, based on differences in endonuclease recognition sites in their $16 \mathrm{~S}$ rDNA sequences (17). From RFLP data obtained in the present study, it was evident that the TPD phytoplasma was indistinguishable from strain CPY and that both strains differed from existing subgroup strains within group 16SrIV. On this basis, strains TPD and CPY were assigned to a new subgroup, 16SrIV-D.

Delineation of strain subgroups within group $16 \mathrm{SrIV}$ is supported by phylogenetic analysis of $16 \mathrm{~S}$ rDNA sequences with the exception of TLD (=LDT), a phytoplasma from coconut palm with lethal disease in Tanzania, East Africa (28). The 16SrDNA sequences from this strain and LDG, a phytoplasma from coconut with Cape St. Paul wilt in Ghana, West Africa (31), differ sufficiently from each other $(>2.5 \%)$ and from other strains composing lethal yellowing subclade (vii) that these strains were assigned to new subclades, designated (xiii) and (xiv), respectively (32), in accordance with the classification scheme of Gundersen et al. (7). Similarly, using phylogeny as a basis for phytoplasma classification, strains TPD and CPY together with LDY comprised a lineage of strains whose 16S rDNA sequences differed from that of the LY agent by $<1 \%$. Thus, strains TPD and CPY represent additional members of subclade (vii).

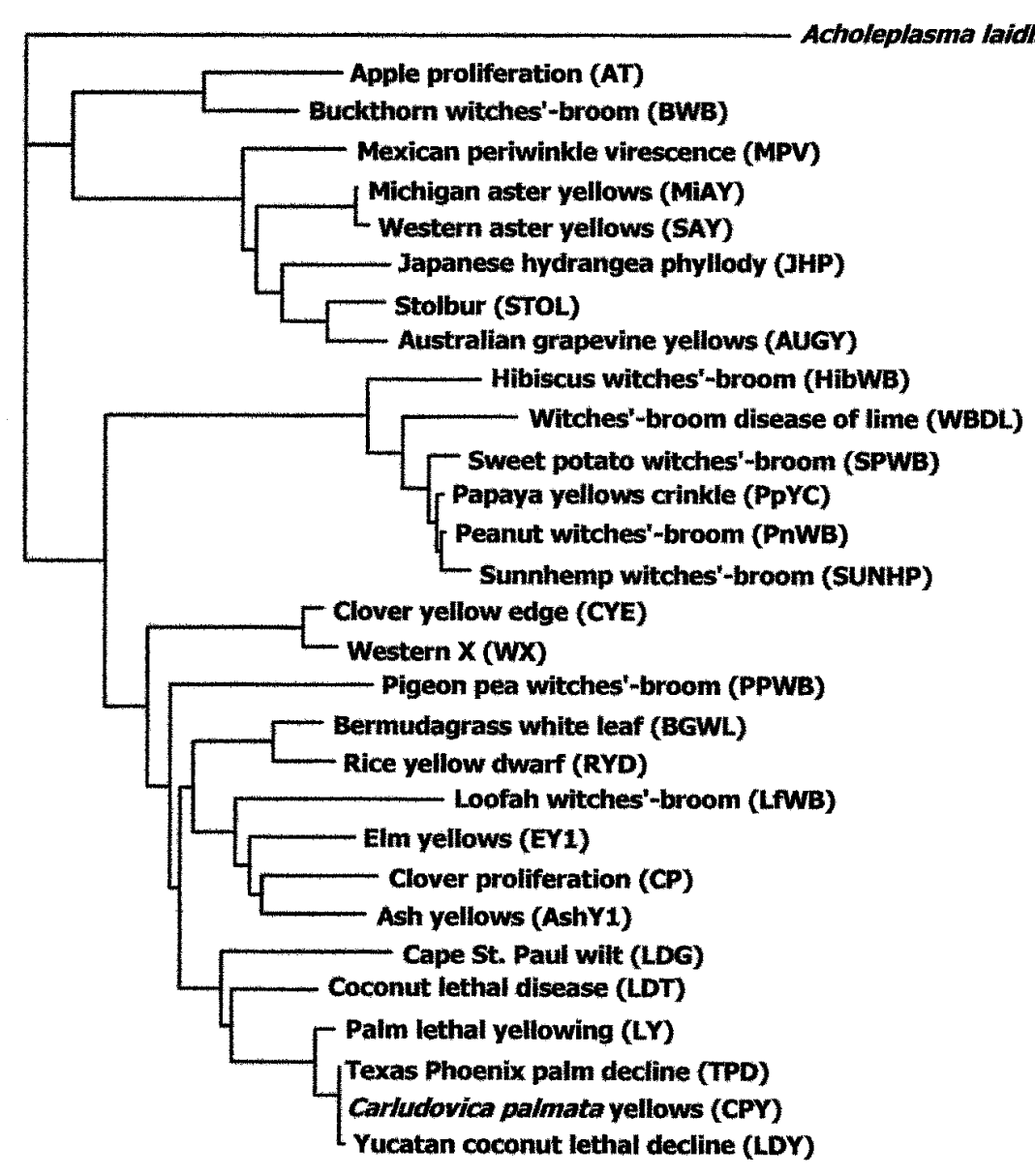

Fig. 5. Phylogenetic tree of $16 \mathrm{~S}$ rRNA gene sequences from 29 phytoplasmas and Acholeplasma laidlawii constructed by the Neighbor-Joining method.

The origin of Texas Phoenix decline in Corpus Christi, a locality with no prior history of unusual losses of Canary Island date palms to disease, is uncertain. It seems possible that the current outbreak may have emerged as a consequence of a recent introduction of infected plants or vector insects from a location some distance from Texas. This hypothesis is supported by the fact that TPD and CPY are very similar, or possibly the same phytoplasma, and while CPY is known to infect C. palmata in Yucatan, Mexico (2), neither strain has been identified before in the United States. Alternatively, the outbreak may reflect a natural northward progression of disease from Brownsville, TX. Observations supporting this hypothesis include the geographic proximity of the two coastal locations (about 160 miles), strong symptomatological similarities between diseases, and its occurrence on a common host, $P$. canariensis. Because we demonstrated the presence of a phytoplasma distinct from the LY agent, this may explain the growing numbers of affected palms in the Corpus Christi area. This epidemiological observation contrasts markedly with that of only minimal losses to LY disease of widely planted $P$. $c a$ nariensis in southern Florida during the last three decades (13).

\section{ACKNOWLEDGMENTS}

We thank B. C. Kirkpatrick, J. H. Tsai, Armando Escamilla, and Ivan Cordova for providing sources of phytoplasma strains used for comparative purposes in this study.

\section{LITERATURE CITED}

1. Altschul, S. F., Gish, W., Miller, W., Myers, E W., and Lipman, D. J. 1990. Basic local alignment search tool. J. Mol. Biol. 215:403410.

2. Cordova, I., Oropeza, C., Almeyda, H., and Harrison, N. A. 2000. First report of a phytoplasma-associated leaf yellowing syndrome of Palma Jipi plants in southern Mexico. Plant Dis. 84:807.

3. Davis, R. E., and Dally, E. L. 2001. Revised subgroup classification of group $16 \mathrm{SrV}$ phytoplasmas and placement of flavescence dorée-associated phytoplasmas in two distinct subgroups. Plant Dis. 85:790-797.

4. Doyle, J. J., and Doyle, J. L. 1990. Isolation of plant DNA from fresh tissue. Focus 12:1315 .

5. Griffiths, H. M., Sinclair, W. A., BoudonPadieu, E., Daire, X., Lee, I.-M., Sfalaga, A., and Bertaccini, A. 1999. Phytoplasmas associated with elm yellows: Molecular variability and differentiation from related organisms. Plant Dis. 83:1101-1104.

6. Griffiths, H. M., Sinclair, W. A., Smart, C. D., and Davis, R. E. 1999. The phytoplasma associated with ash yellows and lilac witches'broom: 'Candidatus Phytoplasma fraxini'. Int. J. Syst. Bacteriol. 49:1605-1614.

7. Gundersen, D. E., Lee, I.-M., Rehner, S. A., Davis, R. E., and Kingsbury, D. T. 1994. Phylogeny of mycoplasmalike organisms (phyto- 
plasmas): A basis for their classification. J. Bacteriol. 176:5244-5254.

8. Gundersen, D. E., Lee, I.-M., Schaff, D. A., Harrison, N. A., Chang, C. J., Davis, R. E., and Kingsbury, D. T. 1996. Genomic diversity and differentiation among phytoplasma strains in $16 \mathrm{~S}$ rRNA group I (aster yellows and related phytoplasmas) and III (X-disease and related phytoplasmas). Int. J. Syst. Bacteriol. 46:64-75.

9. Harrison, N. A., Griffiths, H. M., Carpio, M. L., and Richardson, P. A. 2001. Detection and characterization of an elm yellows $(16 \mathrm{SrV})$ group phytoplasma infecting Virginia creeper plants in southern Florida. Plant Dis. 85:1055-1062.

10. Harrison, N. A., and Oropeza, C. 1997. Recent studies on detection of lethal yellowing disease phytoplasmas in the Americas. Pages 221-234 in: Proceedings of an International Workshop on Lethal Yellowing-Like Diseases of Coconut, Elmina, Ghana, November 1995. S. J. Eden-Green and F. Ofori, eds. Natural Resources Institute, UK.

11. Harrison, N. A., Richardson, P. A., Kramer, J. B., and Tsai, J. H. 1994. Detection of the phytoplasma associated with lethal yellowing disease of palms in Florida by polymerase chain reaction. Plant Pathol. 43:998-1008.

12. Harrison, N. A., Tsai, J. H., Bourne, C. M., and Richardson, P. A. 1991. Molecular cloning and detection of chromosomal and extrachromosomal DNA of mycoplasmalike organisms associated with witches'-broom disease of pigeon pea in Florida. Mol. PlantMicrobe Interact. 4:300-307.

13. Howard, F. W., and Barrant, C. I. 1989. Questions and answers about lethal yellowing disease. Principes 33:163-171.

14. Innis, M. A., and Gelfand, D. H. 1990. Optimization of PCRs. Pages 3-12 in: PCR Protocols: A Guide to Methods and Applications. M. A. Innis, D. H. Gelfand, J. J. Sninsky, and T. J. White, eds. Academic Press, San Diego.

15. Kunnimalaiyaan, M., Stevenson, D. M., Zhou, Y., and Vary, P. S. 2001. Analysis of the replicon region and identification of an rRNA operon on pBM400 of Bacillus megaterium QM B1551. Mol. Microbiol. 39:1010-1021.

16. Kuske, C. R., and Kirkpatrick, B. C. 1992. Phylogenetic relationships between the western aster yellows mycoplasmalike organism and other prokaryotes established by $16 \mathrm{~S}$ rRNA gene sequence. Int. J. Syst. Bacteriol. 42:226-233.

17. Lee, I.-M., Gundersen-Rindal, D. E., Davis,
R. E., and Bartoszyk, I. M. 1998. Revised classification scheme of phytoplasmas based on RFLP analyses of $16 \mathrm{~S}$ rRNA and ribosomal protein gene sequences. Int. J. Syst. Bacteriol. 48:1153-1169.

18. Lim, P.-O., and Sears, B. B. 1989. 16S rRNA sequence indicates that plant-pathogenic mycoplasma-like organisms are evolutionarily distinct from animal mycoplasmas. J. Bacteriol. 171:5901-5906.

19. Macrae, A., Rimmer, D. L., and O'Donnell, A. G. 2000. Novel bacterial diversity recovered from the rhizosphere of oilseed rape (Brassica napus) determined by the analysis of $16 \mathrm{~S}$ ribosomal DNA. Antonie Van Leeuenhoek 78:13-21.

20. McCoy, R. E., Howard, F. W., Tsai, J. H., Donselman, H. M., Thomas, D. L., Basham, H. G., Atilano, R. A., Eskafi, F. M., Britt, L., and Collins, M. E. 1983. Lethal Yellowing of Palms. Agric. Exp. Stn. Bull. No. 834. University of Florida, IFAS, Gainesville, FL.

21. McCoy, R. E., Miller, M. E., Thomas, D. L., and Amador, J. 1980. Lethal decline of Phoenix palms in Texas asssociated with mycoplasmalike organisms. Plant Dis. 64:10381040 .

22. McCoy, R. E., Miller, M. E., and Williams, D. S. 1980. Lethal yellowing in Texas Phoenix palms. Principes 24:179-180.

23. Montano, H. G., Davis, R. E., Dally, E. L., Hogenhout, S., Pimentel, J. P., and Brioso, S. T. 2001. 'Candidatus Phytoplasma brasiliense', a new phytoplasma taxon associated with hibiscus witches' broom disease. Int. J. Syst. Evol. Bacteriol. 51:1109-1118.

24. Namba, S., Oyiazu, H., Kato, S., Iwanami, S., and Tsuchizaki, T. 1993. Phylogenetic diversity of phytopathogenic mycoplasmalike organisms. Int. J. Syst. Bacteriol. 43:461-467.

25. Padovan, A., Gibb, K., Daire, X., and Boudon-Padieu, E. 1996. A comparison of phytoplasma associated with Australian grapevine yellows to other phytoplasmas in grapevine. Vitis 35:189-194.

26. Page, R. D. 1996. TreeView: An application to display phylogenetic trees on personal computers. Comput. Appl. Biosci. 12:357358 .

27. Sawayanagi, T., Horikoshi, N., Kanehira, T., Shinohara, M., Bertaccini, A., Cousin, M.-T., Hiruki, C., and Namba, S. 1999. 'Candidatus Phytoplasma japonicum', a new phytoplasma taxon associated with Japanese hydrangea phyllody. Int. J. Syst. Bacteriol. 49:12751285.

28. Schuiling, M., and Mpunami, M. M. 1990.
The lethal disease of coconut in Tanzania: Review of research and preliminary results of resistance trials. Pages 171-183 in: La problematica del amarillamientoletal de cocotero en Mexico. M. L. Robert and D. Zizumbo, eds. Centro de Investigación Científica de Yucatan, Mérida, México.

29. Seemüller, E., Marcone, C., Lauer, U., Ragozzino, A., and Goeschl, M. 1998. Current status of molecular classification of the phytoplasmas. J. Plant Pathol. 80:3-26.

30. Smart, C. D., Schneider, B., Blomquist, C. L. Guerra, L. J., Harrison, N. A., Ahrens, U., Lorenz, K.-H., Seemüller, E., and Kirkpatrick, B C. 1996. Phytoplasma-specific PCR primers based on sequences of the 16-23S rRNA spacer region. Appl. Environ. Microbiol. 62:2988-2993.

31. Tymon, A., and Jones, P. 1997. Comparative analysis of coconut phytoplasmas from East and West Africa. Pages 197-203 in: Proceedings of an International Workshop on Lethal Yellowing-Like diseases of Coconut, Elmina, Ghana, November 1995. S. J. Eden-Green and F. Ofori, eds. Natural Resources Institute, UK.

32. Tymon, A. M., Jones, P., and Harrison, N. A. 1998. Phylogenetic relationships of coconut phytoplasmas and the development of specific oligonucleotide PCR primers. Ann. Appl. Biol. 132:437-452.

33. Weisburg, W. G., Tully, J. G., Rose, D. L., Petzel, J. P., Oyaizu, H., Mandelco, L. Sechrest, J., Lawrence, T. G., Van Etten, J., Maniloff, J., and Woese, C. R. 1989. A phylogenetic analysis of the mycoplasmas: Basis for their classification. J. Bacteriol. 171:64556467.

34. White, D. T., Blackall, L. L., Scott, P. T., and Walsh, K. B. 1998. Phylogenetic positions of phytoplasmas associated with dieback, yellow crinkle and mosaic diseases of papaya, and their proposed inclusion in 'Candidatus Phytoplasma australiense' and a new taxon, 'Candidatus Phytoplasma australasia'. Int. J. Syst. Bacteriol. 48:941-951.

35. Zheng, X. Y., and Sinclair, J. B. 2000. The effects of traits of Bacillus megaterium on seed and root colonization and their correlation with the suppression of Rhizoctonia root rot of soybean. Biocontrol 45:223-243.

36. Zreik, L., Carle, P., Bové, J. M., and Garnier, M. 1995. Characterization of the mycoplasmalike organism associated with witches'broom disease of lime and proposition of a Candidatus taxon for the organism, "Candidatus Phytoplasma aurantifolia”. Int. J. Syst. Bacteriol. 45:449-453. 